\title{
Reporting the Toxicological Profile of Methanolic Leaf Extract of Anthocleista vogelii Planch on Wistar Rats
}

\author{
${ }^{* 1}$ APIAMU, A; ${ }^{2}$ ASAGBA, SO; ${ }^{2}$ TONUKARI, NJ \\ ${ }^{I}$ Department of Biochemistry, College of Natural and Applied Sciences, Western Delta University, P.M.B. 10, Oghara, Nigeria. \\ ${ }^{2}$ Department of Biochemistry, Faculty of Science, Delta State University, P.M.B. 1, Abraka, Nigeria. \\ *Correspondence Author Email: austodacademia.edu@gmail.com;Tel: +2347060440357
}

\begin{abstract}
The study was aimed at explaining the toxicological profile of crude methanolic leaf extract of Anthocleista vogelii on animal models. In a time-dependent study, the oral acute and subacute toxicity of $70 \%$ methanolic leaf extract of the plant in Wistar rats was investigated through examination of mortality rate, body and organ weight changes, and biomarkers of hepatic and renal functions in all treatment groups. No significant change $(p>0.05)$ was observed for body and organ weights in both studies. The acute toxicity studies demonstrated no death of animals and the $\mathrm{LD}_{50}$ was considered higher than $3200 \mathrm{mg} / \mathrm{kg}$ (p.o). In the subacute toxicity studies, the plant extract indicated no significant effect $(\mathrm{p}>0.05)$ on serum alanine aminotransferase (ALT), aspartate aminotransferase (AST) and alkaline phosphatase (ALP) activities, but with marked significant increase $(\mathrm{p}<0.05)$ on hepatic and renal AST, ALT and ALP activities among treatment groups relative to control. There was no marked significant effect $(\mathrm{p}>0.05)$ on serum total protein (TP), blood urea nitrogen (BUN), albumin (ALB) and creatinine (CREA) levels for all treatment groups except for group I rats, where the oral administration of $800 \mathrm{mg} / \mathrm{kg}$ leaf extract caused a marked significant increase $(\mathrm{p}<0.05)$ in BUN levels relative to control. Therefore, it was inferred from the study that $A$. vogelii leaves exhibited protective and hyper-stimulating properties as well as being innocuous and safe for therapeutic applications.
\end{abstract}

\section{DOI: https://dx.doi.org/10.4314/jasem.v22i6.8}

Copyright: Copyright (C) 2018 Apiamu et al. This is an open access article distributed under the Creative Commons Attribution License (CCL), which permits unrestricted use, distribution, and reproduction in any medium, provided the original work is properly cited.

Dates: Received: 15 April 2018; Revised: 07 June: 2018; Accepted: 19 June 2018

Keywords: Acute toxicity, Anthocleista vogelii, subacute toxicity, $\mathrm{LD}_{50}$

The relevance of plants to life sustenance was examined historically and scientifically to encompass its medicinal and nutritional enrichments. This consequently necessitated scientific research to proffering baseline safety for its therapeutic and nutritional benefits to man. Ouedraogo et al., (2007) reiterated the broad spectrum of traditional applications of plants in the treatment of diverse pathological conditions in Africa with diverse cultural heritage, owing to its availability and inexpensiveness. Today in West Africa, particularly Nigeria, the larger population readily relies on herbal medicine comparable to modern medicine, and this was associated with its affordability and accessibility though effective, but with potential toxic effects (Hostettmann and Marson, 2007). Curative herbs, otherwise called "Medicinal Plants" are usually characterized by intrinsic bioactive compounds with identified pharmacologic impacts known to enhance health exclusively, additively or synergistically (Azaizeh, 2005). The identification and isolation of bioactive compounds from plants as a bedrock of important drugs in contemporary medicine instigated the enthusiasm of researchers in the unceasing assessment of these compounds for chemotherapy
(Wintola et al., 2010). This research drive in ethnomedicine was consolidated through thorough systematic surveys of their potency and probable toxicological indications on animal models respectively (Ashafa et al., 2010; Ashafa and Olunu, 2011; Manal et al., 2016). It was indicated in scientific reports that toxicological assessment of plants generally was relevant in the enhancement of traditional medicine and the formulation of new drugs in modern medicine for efficacy, safety and quality respectively (Firenzuoli and Gori, 2007; Fransworth, 1994; Rousseaux and Scachter, 2003). Therefore, the consideration of Anthocleista vogelii in the present study was associated with its numerous pharmacologic properties, as reported by Anyanwu et al., (2015).

A. vogelii, a popularly known cabbage tree among fourteen other anthocleista species, was reported to show much preference for terrestrial habitat with supportive role for epiphytes (Edwin-Wosu et al., 2015). Although the applications of various parts of A. vogelii span across diverse domestic and industrial domains, but its medicinal value cuts the interests of most researchers. Regardless of the method of preparation and aerial parts of the plant employed, $A$. vogelii was reported to be potent in the treatment of

*Correspondence Author Email: austodacademia.edu@gmail.com ; Tel: +2347060440357 
laxation and purgation, constipation, malarial and typhoid fever, diabetes mellitus, sexually transmitted diseases (STDs), stomach aches, hypertension and a host of others (Anyanwu et al., 2015; Ateufack et al., 2014; Kadiri, 2009; Musa et al., 2010; Olubomehin et al., 2013). The chemical constituents validating their pharmacologic properties were earlier reported to be found in the roots, stems and leaves of $A$. vogelii, and the various bioactive compounds notably; alkaloids, terpenoids, anthraquinones, saponins, tannins, flavonoids, steroids and phenolics with the exception of glycosides were scientifically revealed (Anyanwu et al., 2013; Anyanwu et al., 2015; Apiamu et al., 2017; Gboeloh et al., 2014; Jegede et al., 2011). To this end, the aerial parts of the plant distinctly and evidently exhibited antidiabetic, antiplasmodial, antimicrobial, antihypertensive and antihypotensive, spasmolytic and spasmogenic, anti-obesity and antioxidant properties respectively (Alaribe et al., 2012; Anyanwu et al., 2013; Ateufack et al.,2010; Christophe et al., 2015; Okokon et al., 2012; Olubomehin et al., 2013; Sunday et al., 2014). Therefore, the present study explains the toxicological profile of methanolic leaf extract of $A$. vogelii Planch on rat models via monitoring of toxicity-related biomarkers.

\section{MATERIALS AND METHODS}

Chemicals: The chemical reagents employed for the present study were all analytical grades, prepared in accordance with procedural specifications.

The Plant of Study: The plant, A. vogelii Planch, was harvested for from the environment of Western Delta University, Oghara, Delta State. It was identified and authenticated by a taxonomist, Dr. H. A. Akinnibosun at the Department of Botany, University of Benin, Edo State, Nigeria, where a specimen with voucher number of UBHa0258 was deposited in his herbarium.

Animals: Forty male Wistar rats of 5-6 weeks old were obtained for the study and housed in standard metabolic cages at room temperature, $\left(28 \pm 2{ }^{\circ} \mathrm{C}\right)$, throughout the experimental period with 12-h day, $12-$ $\mathrm{h}$ night cycle. The animals were allowed free access to pelleted livestock feed and water ad libitum. The animals were then allowed to acclimatize for one week, and weekly body weights were recorded during the experimental period. All experiments was conducted in accordance with the Guide for the Care and Use of Laboratory animals, as approved by the Ethical Committee of the Delta State University.
Preparation of plant sample: After fourteen days of drying at room temperature, pulverized, powdered plant material (913 g) was extracted with $70 \%$ methanol by cold maceration for 4 days, and the extraction process was repeated twice. The extract was then concentrated to dryness at $40^{\circ} \mathrm{C}$ using a rotary evaporator (Buchi Rotavator-R, China) under reduced pressure to yield $146.8 \mathrm{~g}(16.08 \%)$. The concentrated extract was weighed and stored in an air-tight container and kept in the refrigerator at $4^{\circ} \mathrm{C}$ for further use.

Acute toxicity assessment: Acute toxicity survey was evaluated following the method put forward by Organization for Economic Cooperation and Development (OECD), (OECD, 2008a) with minor changes. In a randomized block design, (RBD), twenty male Wistar rats were divided into five experimental groups, lettered A-E and consisting of four Wistar rats each such that group A served as control vehicle receiving $1.0 \mathrm{ml}$ of $80 \%$ tween 80 . Experimental groups B-E received a single oral dose of 400, 800 , 1600 and $3200 \mathrm{mg} / \mathrm{kg}$ of crude methanolic leaf extract of $A$. vogelii, dispersed in tween 80 , and subjected to timely clinical examination for 14days, especially a daily routine check for death of animals. Prior to the $15^{\text {th }}$ day, experimental animals were subjected to 12 18 hours fasting and then sacrificed by heart puncture with excision of lungs, heart, hepatocyte and renal tissues for macroscopic assessment and weight measurement. The $\mathrm{LD}_{50}$ value of plant extract on experimental animals was extrapolated following the above experimental protocol.

Subacute assessment: Subacute toxicity survey was evaluated following the method put forward by Organization for Economic Cooperation and Development (OECD), (OECD, 2008b) with minor changes. In a similar RBD, twenty male Wistar rats were divided into four experimental groups, lettered FI and consisting of five Wistar rats each such that group F served as control vehicle receiving $1.0 \mathrm{ml}$ of $80 \%$ tween 80 .

Experimental groups $\mathrm{G}, \mathrm{H}$ and I received a daily oral dose of 200,400 , and $800 \mathrm{mg} / \mathrm{kg}$ of crude methanolic leaf extract of $A$. vogelii, dispersed in tween 80 , and subjected to timely clinical examination like mortality and behavioural changes for 28 days. Prior to the $29^{\text {th }}$ day, experimental animals were subjected to 12 18 hours fasting and then sacrificed by heart puncture with excision of lungs, heart, hepatocyte and renal tissues for macroscopic assessment and weight measurement. The obtained whole blood and excised hepatocyte and renal tissues were subjected to biochemical analysis. 
Experimental Sampling: At the end of the experimental period, animals were sacrificed by heart puncture. Blood samples were collected immediately into EDTA bottles, where portions were centrifuged at $2,500 \mathrm{~g}$ for $20 \mathrm{mins}$ to get supernatants and stored at $4{ }^{\circ} \mathrm{C}$ until it was used for biochemical analysis. Liver and kidney tissues were excised immediately, washed using chilled saline solution and homogenized (10\% w/v) in ice-cold phosphate buffer (0.01 M, pH 7.4) by means of pre-chilled mortar and pestle. The homogenates were centrifuged at $15,000 \mathrm{~g}$ for $20 \mathrm{~min}$, and the resulting supernatants were kept at $4{ }^{\circ} \mathrm{C}$ for further analysis.

Biochemical examination: The non-enzymatic biochemical indicators notably serum total protein (TP), blood urea nitrogen, (BUN), serum albumin, (ALB) and serum creatinine, (CREA), levels were evaluated following diagnostic kit procedures described by Tietz (1995), Weatherbum (1967), Doumas et al., (1971), and Bartels and Bohmer (1972) respectively. The assessments of aspartate aminotransferase (AST: EC.2.6.1.1) and alanine aminotransferase (ALT: EC.2.6.1.2) activities were done following a diagnostic kit method described by Reitman and Frankel (1957) in respective tissues. Alkaline phosphatase (ALP: EC.3.1.3.1) activity was evaluated in respective tissues following a diagnostic kit procedure outlined by Kochmar and Moss (1976). All biochemical assays were spectrophotometrically based (Thermo-Fischer scientific model: G10SUVVIS).

Statistical analysis: Experimental results were expressed as mean \pm standard error of mean (SEM) for each experimental groups. Analysis of variance (ANOVA) was computed among the mean values of the experimental data to ascertain the level of significance at $95 \%$ confidence interval using GraphPad Prism 6.0 software package, and data with comparative mean values of $p<0.05$ were considered significant.

\section{RESULTS AND DISCUSSION}

The traditional application of $A$. vogelii is snowballed for the management of diverse pathological conditions without consideration of its potential toxicity on human subjects in Nigeria today and in Africa at large. To this end, the present study indicated that a single oral administration of crude methanolic leaf extract of A. vogelii showed no clinical symptoms of toxicity assessment as well as no lethality was recorded for 14 days. Also, the increasing body and organ weights of experimental rats exposed to graded doses of methanolic leaf extract showed no marked significant difference $(p>0.05)$ among treatment groups relative to control, which was a consequence of non-toxic impact (Fig 1 and 2). Since there was no death observed throughout the experimentation, the extrapolated $\mathrm{LD}_{50}$ value of the plant was concluded to exceed $3200 \mathrm{mg} / \mathrm{kg}$. This development corresponded with previous reports that the $\mathrm{LD}_{50}$ of leaf extract of $A$. vogelii exceeded limit dose rate of $2000 \mathrm{mg} / \mathrm{kg}$, suggesting its consideration as innocuous plant material (Anyanwu et al., 2013; Sunday et al., 2014). The harmless nature of methanolic leaf extract was also associated with its capacity not to cause significant depression of growth processes and alteration of cellular metabolism (Anderson et al., 1999; Ige et al., 2011; Nadir and Suat, 2007). Therefore, A. vogelii leaves may be considered nontoxic and safe for its traditional usefulness in the treatment and management of diseases, following Hodge and Steiner toxicity scale (OECD, 2000).

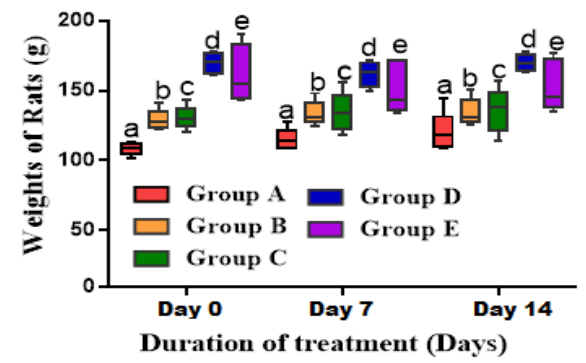

Fig 1: Body weight changes on acute exposure to methanolic leaf extract of $A$. vogelii. Each bar represents mean \pm SEM of five Wistar rats, $(n=5)$, for each group in the same column. Each bar with different letters in the same column differ significantly at $\mathrm{p}<0.05$.

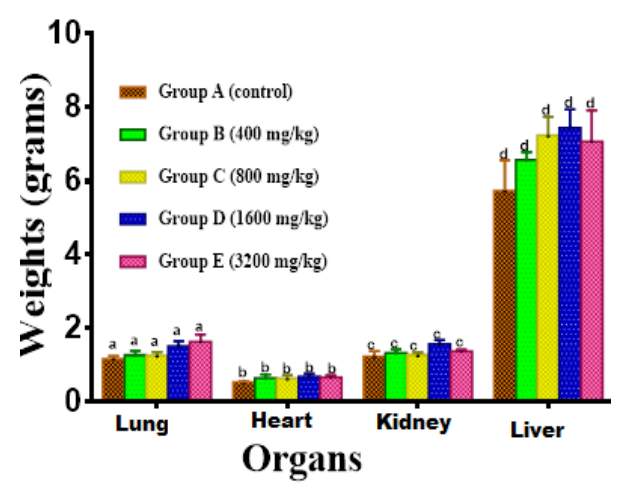

Fig 2: Organ weight changes on acute exposure to methanolic leaf extract of A. vogelii. Each bar designates mean \pm SEM of five Wistar rats, $(n=5)$, for each group in the same column. Each bar with different letters in the same column differ significantly at $\mathrm{p}<0.05$.

The subacute monitoring of Wistar rats exposed to daily oral administration of methanolic leaf extract recorded no death rate among treatment groups in relation to control group, and Fig 3 and 4 clearly revealed increasing body and organ weights. 


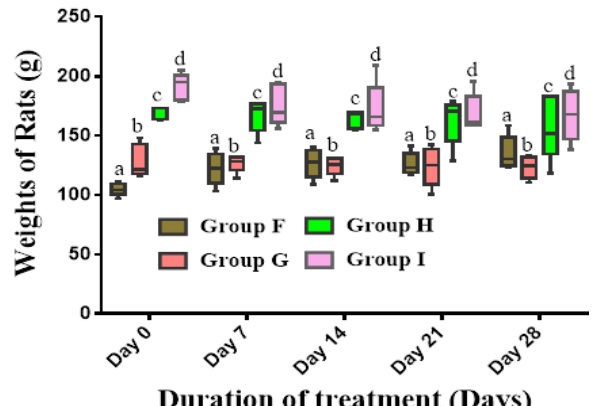

Fig 3: Body weight changes on subacute exposure to methanolic leaf extract of A. vogelii. Each bar represents mean \pm SEM of five Wistar rats, $(n=5)$, for each group in the same column. Each bar with different letters in the same column differ significantly at $\mathrm{p}<0.05$.

However, the plant extract showed no marked significant effect $(0>0.05)$ on body and organ weights of rats among treatment groups in comparison with control group. Therefore, the increasing body and organ weights of rats may be attributed to their feeding habits other than the methanolic leaf extract of $A$. vogelii as well as absence of metabolic alterations. The present observation shows conformity with reported literature, which suggested that a significant reduction in body and organ weights may reflect metabolic sabotage in biological systems (Anderson et al., 1999; Ige et al., 2011; Nadir and Suat, 2007).

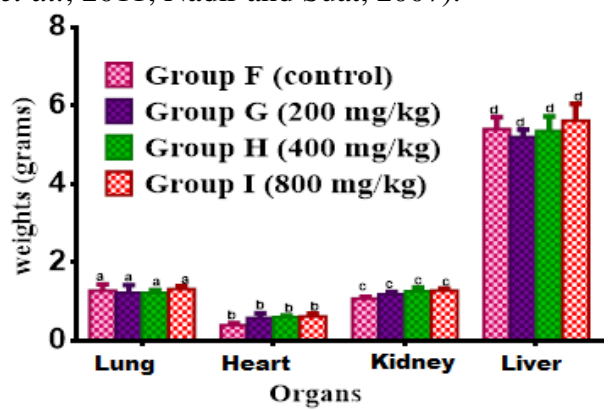

Fig 4: Organ weight changes on subacute exposure to methanolic leaf extract of $A$. vogelii. Each bar designates mean \pm SEM of five Wistar rats, $(n=5)$, for each group in the same column. Each bar with different letters in the same column differ significantly at $\mathrm{p}<0.05$.

The subacute toxicity profile of $A$. vogelii leaves was further supported via evaluation of enzymatic and nonenzymatic biomarkers in hepatocyte and renal tissues of Wistar rats, which may reflect in serum also (Table $1-4)$.

Table 1: Subacute effect of methanolic leaf extract of A. vogelii on non-enzymatic parameters in Wistar rats.

\begin{tabular}{lllll}
\hline Assay parameters & $\begin{array}{l}\text { Group F } \\
\text { (control) }\end{array}$ & $\begin{array}{l}\text { Group G } \\
\mathbf{2 0 0} \mathbf{~ m g / k g}\end{array}$ & $\begin{array}{l}\text { Group H } \\
\mathbf{4 0 0} \mathbf{~ m g / k g}\end{array}$ & $\begin{array}{l}\text { Group I } \\
\mathbf{8 0 0} \mathbf{~ m g / k g}\end{array}$ \\
\hline TP $(\mathrm{g} / \mathrm{dl})$ & $2.67 \pm 0.10^{\mathrm{a}}$ & $2.32 \pm 0.51^{\mathrm{a}}$ & $2.25 \pm 0.16^{\mathrm{a}}$ & $2.59 \pm 0.28^{\mathrm{a}}$ \\
ALB $(\mathrm{g} / \mathrm{dl})$ & $1.28 \pm 0.07^{\mathrm{b}}$ & $1.99 \pm 0.37^{\mathrm{b}}$ & $2.89 \pm 0.89^{\mathrm{b}}$ & $2.71 \pm 0.20^{\mathrm{b}}$ \\
BUN (mg/dl) & $35.49 \pm 1.19^{\mathrm{a}}$ & $36.72 \pm 1.48^{\mathrm{a}, \mathrm{b}}$ & $51.68 \pm 6.06^{\mathrm{b}}$ & $75.36 \pm 1.99^{\mathrm{c}}$ \\
CREA (mg/dl) & $1.02 \pm 0.05^{\mathrm{c}}$ & $0.63 \pm 0.20^{\mathrm{c}}$ & $0.78 \pm 0.07^{\mathrm{c}}$ & $0.98 \pm 0.04^{\mathrm{c}}$ \\
\hline
\end{tabular}

*Experimental data are represented as mean \pm standard error of mean (SEM of five Wistar rats. The mean values with different letters were considered to be statistically significant $(p<0.05)$ across respective groups.

Table 2: Subacute effect of methanolic leaf extract of A. vogelii on serum enzymatic parameters in Wistar rats.

\begin{tabular}{lllll}
\hline $\begin{array}{l}\text { Assay parameters } \\
\text { (U/L) }\end{array}$ & $\begin{array}{l}\text { Group F } \\
\text { (control) }\end{array}$ & $\begin{array}{l}\text { Group G } \\
\mathbf{2 0 0} \mathbf{~ m g / k g}\end{array}$ & $\begin{array}{l}\text { Group H } \\
\mathbf{4 0 0} \mathbf{~ m g / k g}\end{array}$ & $\begin{array}{l}\text { Group I } \\
\mathbf{8 0 0} \mathbf{~ m g} / \mathbf{k g}\end{array}$ \\
\hline ALT & $84.44 \pm 1.77^{\mathrm{a}}$ & $97.59 \pm 6.98^{\mathrm{a}}$ & $101.07 \pm 4.90^{\mathrm{a}}$ & $101.20 \pm 2.16^{\mathrm{a}}$ \\
AST & $84.60 \pm 8.08^{\mathrm{b}}$ & $107.33 \pm 5.77^{\mathrm{b}}$ & $105.00 \pm 0.42^{\mathrm{b}}$ & $104.73 \pm 7.14^{\mathrm{b}}$ \\
ALP & $13.37 \pm 3.40^{\mathrm{c}}$ & $19.91 \pm 4.18^{\mathrm{c}}$ & $20.74 \pm 4.00^{\mathrm{c}}$ & $24.26 \pm 2.45^{\mathrm{c}}$ \\
\hline
\end{tabular}

*Investigational data are represented as mean \pm standard error of mean (SEM of five Wistar rats. The mean values with different letters were considered to be statistically significant $(p<0.05)$ across respective groups.

Table 3: Subacute effect of methanolic leaf extract of A. vogelii on hepatocyte enzymatic parameters in Wistar rats.

\begin{tabular}{lllll}
\hline $\begin{array}{l}\text { Assay parameters } \\
\text { (U/L) }\end{array}$ & $\begin{array}{l}\text { Group F } \\
\text { (control) }\end{array}$ & $\begin{array}{l}\text { Group G } \\
\mathbf{2 0 0} \mathbf{~ m g / k g}\end{array}$ & $\begin{array}{l}\text { Group H } \\
\mathbf{4 0 0} \mathbf{~ m g / k g}\end{array}$ & $\begin{array}{l}\text { Group I } \\
\mathbf{8 0 0} \mathbf{~ m g} / \mathbf{k g}\end{array}$ \\
\hline ALT & $88.00 \pm 3.07^{\mathrm{a}}$ & $110.95 \pm 4.69^{\mathrm{b}}$ & $170.57 \pm 6.43^{\mathrm{c}}$ & $141.56 \pm 2.62^{\mathrm{d}}$ \\
AST & $126.77 \pm 2.29^{\mathrm{a}}$ & $155.68 \pm 1.12^{\mathrm{b}}$ & $167.83 \pm 1.14^{\mathrm{c}}$ & $178.95 \pm 2.40^{\mathrm{d}}$ \\
ALP & $26.71 \pm 0.60^{\mathrm{a}}$ & $33.58 \pm 1.76^{\mathrm{b}}$ & $32.43 \pm 1.69^{\mathrm{b}}$ & $38.85 \pm 1.67^{\mathrm{c}}$ \\
\hline
\end{tabular}

*Experimental data are represented as mean \pm standard error of mean (SEM of five Wistar rats. The mean values with different letters were considered to be statistically significant $(p<0.05)$ across the respective groups.

Table 4: Subacute effect of methanolic leaf extract of A. vogelii on renal enzymatic parameters in Wistar rats.

\begin{tabular}{lllll}
\hline $\begin{array}{l}\text { Assay parameters } \\
\text { (U/L) }\end{array}$ & $\begin{array}{l}\text { Group F } \\
\text { (control) }\end{array}$ & $\begin{array}{l}\text { Group G } \\
\mathbf{2 0 0} \mathbf{~ m g} / \mathbf{k g}\end{array}$ & $\begin{array}{l}\text { Group H } \\
\mathbf{4 0 0} \mathbf{~ m g / k g}\end{array}$ & $\begin{array}{l}\text { Group I } \\
\mathbf{8 0 0} \mathbf{~ m g} / \mathbf{k g}\end{array}$ \\
\hline ALT & $66.99 \pm 3.86^{\mathrm{a}}$ & $91.22 \pm 5.97^{\mathrm{a}}$ & $119.28 \pm 5.71^{\mathrm{b}}$ & $135.77 \pm 8.13^{\mathrm{c}}$ \\
AST & $83.81 \pm 1.57^{\mathrm{a}}$ & $100.33 \pm 1.04^{\mathrm{a}}$ & $116.23 \pm 3.52^{\mathrm{b}}$ & $150.84 \pm 5.79^{\mathrm{c}}$ \\
ALP & $181.56 \pm 3.45^{\mathrm{a}}$ & $212.63 \pm 4.19^{\mathrm{b}}$ & $228.75 \pm 4.88^{\mathrm{b}}$ & $266.64 \pm 8.47^{\mathrm{c}}$ \\
\hline
\end{tabular}

Experimental data are represented as mean \pm standard error of mean (SEM of five Wistar rats. The mean values with different letters were considered to be statistically significant $(p<0.05)$ across the respective groups. 
Crook (2006) emphasized hepatocyte as a primary biological centre for innumerable metabolic processes with increasing rate of food metabolism and detoxification of drugs and other xenobiotics. Therefore, hepatocyte function tests, encompassing secretory variables like serum proteins, albumin and many more, and excretory variables like bilirubin and bile were suggested to be relevant in the toxicological assessment of medicinal plants and other chemical agents on biological systems, and a fall of these variables below reference standard may be a reflection of hepatotoxicity (Ajayi and Akhigbe, 2014). On the other hand, the evaluation of creatinine, urea and electrolyte levels as an assembly of renal function tests were scientifically useful biomarkers of renal toxicity (Akhigbe, 2014; Sembulingam and Sembulingam, 2010). The oral administration of crude methanolic leaf extract of A. vogelii at 200, 400 and $800 \mathrm{mg} / \mathrm{kg}$ for treatment groups in relation to control vehicle showed no marked significant difference $(p>0.05)$ for serum TP, ALB, BUN and CREA levels respectively (Table 1). However, oral administration of $800 \mathrm{mg} / \mathrm{kg}$ plant extract resulted in significant increase $(\mathrm{p}<0.05)$ of serum BUN levels for group I rats relative to control group. This development may not adequately support renal toxicity, owing to the fact that there was no significant alteration ( $p>0.05)$ of CREA levels among treatment groups relative to the control vehicle until, otherwise, proven scientifically and specifically by these biomarkers in renal tissue. At this juncture, the development may be linked to previous studies, suggesting that significant increase in BUN levels in serum may be a metabolic reflection of protein metabolism after ingestion of protein-rich meal, hydration and gastrointestinal haemorrhage (Dzoyem et al., 2015; Mezui et al., 2015). This was also validated by a report written by Haschek et al. (2009), indicating that a case of renal azotemia may be characterized by steady significant enhancement of serum BUN and CREA concentrations. Consequently, the statistically insignificant effect on serum nonenzymatic parameters was a clear-cut indication that oral administration of crude methanolic leaf extract of the plant showed no hepatotoxicity and renal toxicity, especially at dose rate range of $200-400 \mathrm{mg} / \mathrm{kg}$. This observation agrees with Ayoka et al., (2010), suggesting that $A$. vogelii exhibits hepatoprotective property.

The protective and stimulating actions of crude methanolic leaf extract of $A$. vogelii was biomonitored via the assessment of ALT, AST and ALP activities in hepatocyte and renal tissues respectively (Tables 2-4). Studies suggested the toxicological relevance of these enzymes in ascertaining the degree of cellular architectural maintenance, especially in the assessment of disruption rate of biological membrane integrity as well as subsequent leakages into blood stream (Abel and Banjo, 2012; Akhigbe, 2014). Functionally. the involvement of AST and ALT activities in transamination reactions under the influence of pyridoxal phosphate cofactor were reported to be associated with protein and carbohydrate metabolism, and their tissue distribution was employed in biochemical assessment of toxicity in tissues (Mezui et al., 2015). The universal distribution of AST in the cytoplasmic pool of tissues like liver, kidney, heart, muscles, spleen and others with much amount in their mitochondria gave a disparity in relation to ALT, whose activity is strictly localized in the cytoplasm of hepatocyte (Abel and Banjo, 2012; Akhigbe, 2014; Magnifouet et al., 2011; Mezui et al., 2015; York, 2017). This resulted in the application of ALT activity as a definite biomarker for hepatocellular injury while AST activity may not be adequate as a lone biomarker for hepatocellular injury, except employed together (Idoh et al., 2016; Ogbe et al., 2012; York, 2017). Again, ALP activity, which is primarily localized in membranes of osteoblastic cells of bones, mammary gland, placental, intestinal mucosa, renal proximal tubules and hepatocytes, where it functions in the alkaline hydrolysis of organophosphates to maintain biological membrane integrity. (Ramaiah, 2007; Dzoyem et al., 2014; Sharma et al., 2014). Thus, Dzoyem et al. (2014); Ogbe et al., (2012); Vasudevan and Sreekumari (2007) examined comparatively, the toxicological relevance of ALP activity as a useful indicator of cholestasis and hepatobiliary injury, while ALT and AST activities were essential biomarkers employed for biomonitoring of hepatocellular damage when biological organisms are exposed to stressors From the present study, Table 2 showed increasing serum AST, ALT and ALP activities without significant impact $(p>0.05)$ among treatment groups relative to control group on exposure to methanolic leaf extract of the plant, suggesting that there was no damage to hepatocyte and renal tissues. However, Tables 3 and 4 showed marked significant increase of AST, ALT and ALP activities on exposure to crude leaf extract among treatment groups relative to control group, indicating stimulating action of the plant. Therefore, the present study validated earlier reports that $A$. vogelii exhibited hepatoprotective, hepato-stimulating as well as renal-stimulating properties regardless of its aerial part employed (Ayoka et al., 2014; Iroanya et al., 2015).

Conclusion: The results of the present empirical survey portended that $A$. vogelii leaves exhibited no toxic property, and its safe folkloric application in the treatment of diverse pathologies is definite since death of any sort was not observed during acute and subacute 
examinations of Wistar rats. The results obtained in the present study also suggested that $A$. vogelii leaves exhibited protective and hyper-stimulating effects on hepatic and renal functions of Wistar rats.

Acknowledgement: On behalf of the research group, we are sincerely thankful to Mr Festus Oguni from biochemistry laboratory, Department of Biochemistry, Western Delta University, Oghara, Nigeria, for his technical support and provisions in the successful completion of this research publication.

\section{REFERENCES}

Abel, AA; Banjo, AD (2012). Honeybee floral resources in Southwestern Nigeria. J. Biol. Life Sci. 3(1):2157-2176.

Ajayi, AF; Akhigbe, RE (2012). Implication of altered thyroid state on liver function. Thyroid Res. Pract. 9:84-87.

Akhigbe, RE (2014). Discordant results in plant toxicity studies in Africa: attempt of standardization. In: Kuete, V (ed). Toxicological Survey of African Medicinal Plants 32 Jamstown Road London NW1 7BY: Elsevier Inc, p. 80-97.

Alaribe, CSA; Coker, HAB; Shode, FO; Ayoola, G; Adesegun, SA; Bamiro, J; Anyim, EI; Anyakora, C (2012). Antiplasmodial and phytochemical investigations of leaf extract of Anthocleista vogelii (Planch). J. Nat. Prod. 5: 60-67.

Anderson, H; Larsen, S; Splid, H; Christenson, ND (1999). Multivariate statistical analysis of organ weights in toxicity studies. Toxicol. 9:136-167.

Anyanwu, GO; Onyeneke, EC; Rehman, N; Rauf, K (2015). Medicinal plant of the genus Anthocleista - A review of their ethnobotany, phytochemistry and pharmacology. J. Ethnopharmacol. 175: 648667.

Anyanwu, GO; Onyeneke, EC; Usunobun, U; Adegbegi, AJ (2013). Impact of Anthocleista vogelii root bark ethanolic extract on weight reduction in high carbohydrate diet induced obesity in male wistar rats. Afr. J. Biochem. Res. 7:225-232.

Apiamu, A; Asagba, SO; Tonukari, NJ (2017). In vitro phytochemistry and Nutritional status of Anthocleista vogelii. NJPASR 6(2): 44-50.
Ashafa, A; Olunu, O. (2011). Toxicological evaluation of ethanolic root extract of Morinda Lucida (L) Benth. (Rubiaceae) in male Wistar rats. J. Nat. Pharm. 2:108- 114.

Ashafa, A; Sunmonu, T; Afolayan, A (2010). Toxicological evaluation of aqueous leaf and berry extracts of Phytolacca dioical in male Wistar rats. Food Chem. Toxicol. 48: 1886-1889.

Ateufack, G; Nguelefack, TB; Wabo, HK; Tane, P; Kamanyi, AG (2014). Antiulcerogenic activity of 1-hydroxy-3, 7, 8trimethoxyxanthone isolated from the methanol extract of Anthocleista vogelii Planch in rats. Ulcers 14: 1-6.

Ayoka, AO; Okonji, RE; Ofusori, DA; Komolafe, OA; Bamitale, KDS; Fakunle, JB (2014). Effect of Xylopia aethiopica, Fiscus mucuso and Anthocleista vogelli extracts on some biochemical parameters following ethanol-induced toxicity. British J. Med. Med. Res. 4: 27052712.

Azaizeh, CG (2005). Ethnobotanical knowledge of local Arab practitioners in the Middle Eastern region. Fitoterapia 74: 98-108.

Bartels, H; Bohmer, M (1972). Method of creatinine assay. Clin. Chem. Acta 37: 193.

Christophe, M; Frida, L; Celine, N; Zacharie, S; Emilie, N; Paul, VT (2015). Evaluation of acute and subacute toxicity of stem bark aqueous extract of Anthocleista schweinfurthii (Loganiaceae). World J. Pharm. Pharmaceut. Sci. 4: 197-208.

Crook, MA (2006). Clinical chemistry and metabolic medicine. 7th ed. London, UK: Edward Arnold Publishers Ltd.

Doumas, BT; Watson, WA; Biggs, HG (1971). Albumin standards and the measurement of serum albumin with bromocresol green, Clinica Chimie Acta 31: 87.

Dzoyem, JP; Kuete, V; Eloff, JN (2014). Biochemical parameters in toxicological studies in Africa: significance, principle of methods, data interpretation, and use in plant screenings. In: Kuete, V (ed). Toxicological Survey of African Medicinal Plants 32 Jamstown Road London NW1 7BY: Elsevier Inc, p. 686-742). 
Edwin-Wosu, NL; Omara-Achong, T; Nkang, A (2015). Distribution, habitat adaptation and conservation as integral approach to protection of Anthocliesta species in Nigeria's Niger Delta Landscape. Asian J. Plant Sci. Res. 5: 1726.

Firenzuoli, F; Cori, L (2007). Herbal medicine today: Clinical and research issues. Evd. Based Compl. Alternat. Med. 4:37-40.

Fransworth, N (1994). Ethnopharmacology and drug development. In: Prance, G; March, J (eds). Ethnobotany and the search for new drugs, Ciba foundation symposium Vol. 185 John Wiley and sons, Chichester, p. 42-59.

Gboeloh, LB; Okon, OE; Udoh, SE (2014). Antiplasmodial effect of Anthocleista vogelii on albino mice experimentally infected with Plasmodium berghei (NK 65). J. Parasitol. Res. 14: 6.

Haschek, WM; Rousseaux, CG; Wallig, MA (2009). Clinical pathology. In: Haschek, WM; Rousseaux, CG; Wallig, MA (eds). Fundamentals of Toxicologic Pathology, (2 $2^{\text {nd }}$ ed.), London NW1, Academic Press, p. 43-65.

Hostettmann, K; Maston, A (2007). Twenty years of research into medicinal plants: Results and perspectives. Phytochem. Rev. 1: 275-285.

Idoh, K; Agbonon, A; Potchoo, Y; Gbeassor, M (2016). Toxicological assessment of the hydroethanolic leaf extract of Clerodendrum capitatum in Wistar rats. Pan Afr. Med. J. 24: 113.

Ige, SF; Akhigbe, RE; Edeogho, O; Ajao, FO; Owolabi, OQ; Oyekunle, OS (2011). Hepatoprotective activities of Allium cepa in cadmium-treated rats. Int. J. Pharm. Pharmaceut. Sci. 3: 60-63.

Iroanya, O; Oduola, T; Akagha, M; Oladunjoye, E (2015). Pharmacological properties of Anthocleista vogelii against $\mathrm{CCl}_{4}$ - induced toxicity. FASEB J. 29: 721734.

Jegede, IA; Ibrahim, JA; Kunle, OF (2011). Phytochemical and pharmacognostic studies of the leaf and stem-bark of
Anthocleista vogelii (Planch). J/ Med. Plants Res. 5: 6136-6139.

Kadiri, AB (2009). An examination of the usage of herbal contraceptives and abortifacients in Lagos State, Nigeria. Ethnobotanical Leaflets 16.

Kochmar, JF; Moss, DW (1976). Fundamentals of Clinical Chemistry. In: Tietz, NW (ed). W.B. Saunders and Company, Philadelphia, p. 604.

Magnifouet, HN; Ngono, RN; Kuiate, JR; Koanga, LM; Tamokou, JD; Ndifor, F (2011). Acute and subacute toxicity of the methanolic extract of Pteleopsis hylodendron stem bark. J. of Ethnopharmacol. 137:70-76.

Manal, AI; El Bushra, EE; Ahmed, AG (2016). Changes in body weight and serum biochemical parameters of wistar rats orally dosed with Maerua pseudopetalosa (gilg and bened.) De wolf tuber extracts. Eur. J. Res. Med. Sci. 4(1): 52-59.

Mezui, C; Longo, F; Nkenfou, C; Sando, Z; Ndeme, E; Tan, PV (2015). Evaluation of acute and subacute toxicity of stem bark aqueous extract of Anthocleista schweinfurthii (loganiaceae). World J. Pharm. Pharmaceut. Sci. 4(3): 197-208.

Musa, AD, Yusuf, GO; Ojogbane, EB; Nwodo, OFC (2010). Screening of eight plants used in folkloric medicine for the treatment of typhoid fever. J. Chem. Pharmaceut. Res. 2 (4): 7-15.

Nadir, R; Suat, E (2007). Oral administration of lycopene reverses cadmium-suppressed body weight loss and lipid peroxidation in rats. Biol. Trace Elements Res. 118:175-83.

OECD, (Organization for Economic Cooperation and Development), (2008a). Acute oral toxicity - up and down procedure In: OECD Guidelines for the testing of chemicals No. 425. OECD, Paris, France.

OECD, (Organization for Economic Cooperation and Development), (2008b). Repeated dose oral toxicity test method. In: OECD Guidelines for testing of chemicals, No. 407. OECD, Paris, France.

OECD, (Organization for Economic Cooperation and Development), (2000). Guidance document on acute oral toxicity. Environmental health and 
safety monograph series on testing and assessment No.24. OECD, Paris, France.

Ogbe, RJ; Adenkola, AY; Anefu, E (2012). Aqueous Ethanolic Extract of Mangifera indica stem bark effect on the biochemical and haematological parameters of albino rats. Arch. Appl. Sci. Res. 4 (4):1618-1622.

Okokon, JE; Antia, BS; Udobang, JA (2012). Antidiabetic activities of ethanolic extract and fraction of Anthocleista djalonensis. Asian Pacific J. Trop. Biomed. 2: 461-464.

Olubomehin, OO; Abo, KA; Ajaiyeoba, EO (2013). Alpha-amylase inhibitory activity of two Anthocleista species and in vivo rat model anti-diabetic activities of Anthocleista djalonensis extracts and fractions. $J$. Ethnopharmacol. 146: 811-814.

Ouedraogo, Y; Guissou, I.; Nacoulma, O (2007). Biological and toxicology study of aqueous root extract from Mitragyna inermis (Willd Oktze) Rubiaceae. Int. J. Pharmacol. 3: 80-85.

Ramaiah, SK (2007). A toxicologist guide to the diagnostic interpretation of hepatic biochemical parameters. Food Chem. Toxicol. 45:155-167.

Reitman, S; Frankel, S (1957). A colorimetric method for determination of serum glutamate oxaloacetate and glutamic pyruvate transaminase. American J. Clin. Pathol. 28: 5658.

Rousseaux, C; Schachter, H (2003). Regulatory issues concerning the safety, efficacy and quality of herbal remedies. Birth defects research. Part B Develop. Reprod. Toxicol. 68: 505-510.
Sembulingam, K; Sembulingam, P (2010). Essentials of medical physiology. 5th ed., New Delhi, India: Jaypee Brothers Medical Publishers Ltd.

Sharma, U; Pal, D; Prasad, R (2014). Alkaline phosphatase: an overview. Int. J. Clin. Biochem. 29(3): 269-278.

Sunday, R; Ilesanmi, O; Obuotor, E (2014). Anti-diabetic effect of Anthocleista vogelii ethanolic root extract and fractions in wistar rats. Basic Clin. Pharmacol. Toxicol., 115: 1-374.

Tietz, NW (1995). Clinical guide to laboratory tests. 3rd Edition. W.B. Saunders and Company, Philadelphia, PA, p. 518-519.

Vasudevan, DM; Sreekumari, S (2007). Textbook of Biochemistry for Medical Students. 5th ed. New Delhi: Jaypee Brothers Medical Publishers, p. 239-246.

Weatherburn, MW (1967). Phenol-hypochlorite reaction for determination of ammonia. Annals Chem. 39: 971- 974.

Wintola, O; Sunmonu, T; Afolayan, A (2010). The effect of Aloe ferox MIII in the treatment of loperamide-induced constipation in Wistar rats. BMC Gastroenterol. 10: 95.

York, MJ (2017). Clinical pathology. In: Fagi, AS (ed). A comprehensive guide to toxicology in nonclinical drug development, 2nd ed., 125 London Wall, London EC2Y 5AS, United Kingdom, Elsevier Inc, p. 325-374. 